
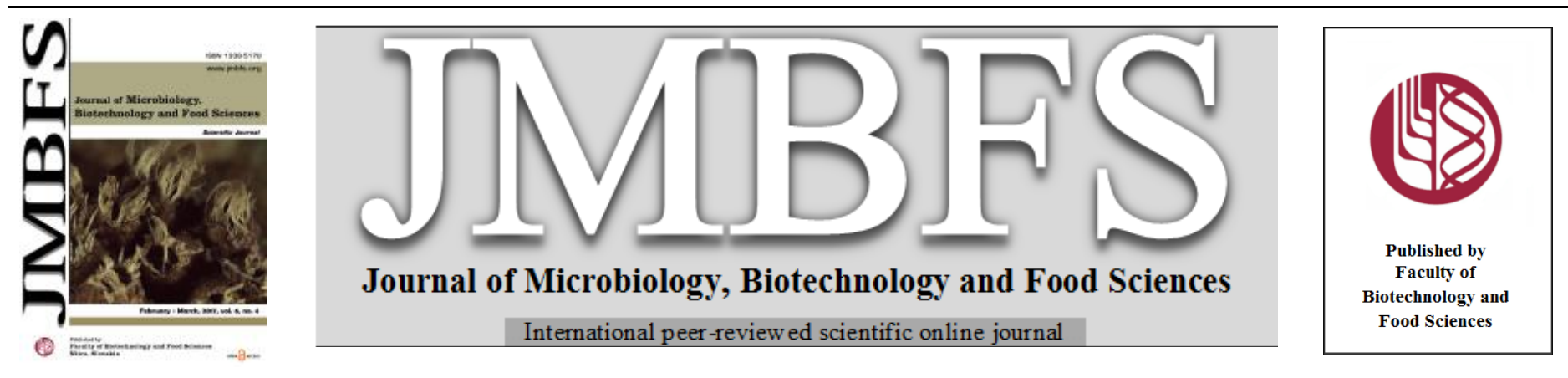

\title{
MOLECULAR AND PHENOTYPIC RESISTANCE OF GROUNDNUT VARIETIES TO LEAF SPOTS DISEASE IN GHANA
}

\author{
David Sewordor Gaikpa ${ }^{* 1}$, Richard Akromah ${ }^{1}$, James Yaw Asibuo ${ }^{2}$, Daniel Nyadanu $^{l}$ \\ Address(es): Mr. David Sewordor Gaikpa, \\ ${ }^{1}$ Crop and Soil Sciences Department, Kwame Nkrumah University of Science and Technology, Kumasi, Ghana. \\ ${ }^{2}$ Council for Scientific and Industrial Research-Crop Research Institute, Fumesua-Kumasi, Ghana.
}

*Corresponding author: davidsewordor@yahoo.com

doi: 10.15414/jmbfs.2017.6.4.1043-1048

\section{ARTICLE INFO}

Received 1. 4. 2016

Revised 12. 8. 2016

Accepted 5. 12. 2016

Published 1. 2. 2017

Regular article

open 2 access

\begin{abstract}
Groundnut yield is constrained in most cases by early and lateleaf spots diseases. Selection and breeding for resistance will enhance yields. Therefore, this study was conducted in Crop Research Institute, Fumesua-Kumasi, Ghana to screen 20 groundnut varieties for leaf spots resistance using both molecular and phenotypic tools. Differences in disease incidence among individual plants, severity score, lesion diameter and defoliation across the 20 genotypes were highly significant $(\mathrm{p}<0.01)$ under phenotypic screening. Fourteen genotypes were moderately resistant while six genotypes were susceptible. The SSR markers pPGseq2F5 280 , pPGseq2B10 $280 / 290$, pPGPseq17F6 $120 / 140 / 150$, PMc588 ${ }_{180 / 220}$ and PM384 ${ }_{100}$ confirmed most resistant genotypes at the molecular level. The resistant genotypes confirmed by the markers were 'ICG7878', 'Obolo', 'Oboshie', 'Jenkaar', 'Adepa', 'Nkosour', 'Azivivi', 'Nkatekokoo', 'Behenase', 'Manipinta', 'Otuhia', 'GK7', 'Nkatiesari' and 'Sumnut22'. Genotypes '55-437', 'Yenyawoso', 'Bremawuo', 'Kumawu', 'Konkoma' and 'Shitaochi' were susceptible. Hence, resistance to leaf spots exists among commercially grown groundnuts in Ghana. Both morphological descriptors and DNA molecular could be used for identification of resistant genotypes.
\end{abstract}

Keywords: Arachis hypogaea, Cercospora, Phenotypic, Resistance, SSR Markers

\section{INTRODUCTION}

Groundnut (Arachis hypogaea L.) is an important legume crop grown globally. It is mostly grown in developing countries of Africa and Asia (FAOSTAT, 2015) In 2014, Ghana was the seventh largest producer of groundnut in Africa with about 426280 tonnes of unshelled groundnuts on a land area of 334000 hectares (FAOSTAT, 2015). The crop is mostly grown in the northern part of Ghana by resource-poor farmers, who in most cases are unable to buy and use fungicide to control diseases (Nutsugahet al., 2007). Groundnut is a good source of minerals, vitamins, plant protein and unsaturated oil for most people in Ghana (Asibuo et al., 2008). Low yields and quality of groundnut in developing countries have been partly attributed to early and late leaf spots disease (Janila et al., 2013a; Gaikpa et al., 2015). Early leaf spot (ELS) is caused by the fungus Cercospora arachidicola Hori and late leaf spots (LLS) by the fungus Cercosporidium personatum Berk. \& M.A. Curtis (Janila et al., 2013a). The $C$. arachidicola forms dark brown lesions that are larger and sub-circular on groundnut leaflets whiles $C$. personatum forms a darker, smaller and more circular lesions on the leaflets. The leaf spots reduce available photosynthetic area of the groundnut plant and also cause abscission of leaflets of the crop (McDonald et al., 1985).

The use of resistant cultivars to manage leaf spots would be cheaper to farmers and environmentally safer compared to application of chemicals. Sources of disease-resistant genotypes and their successful selection are essential for improving commercial cultivars and elite breeding lines (Fehr, 1987). However, sources of cultivated groundnut genotypes for Cercospora leaf spot resistance are reported to be generally scarce (Kishore $\boldsymbol{e t}$ al., 2005). Identification of leaf spot resistant and susceptible lines using conventional screening techniques has been described as difficult, because of its partial and polygenic nature (Dwivedi $\boldsymbol{e t}$ al. 2002; Janila et al., 2013b). Molecular markers, such as simple sequence repeat markers (SSRs), associated with leaf spots resistance have been found to improve the process of identification of resistant genotypes (Mace et al., 2006; Shoba $\boldsymbol{e}$ al., 2012). Early and late leaf spots occur together in Ghanaian farms in most cases. Proper identification of resistant groundnut varieties is very vital for farmers and crop scientists to make informed decisions on the cultivars to grow under a particular condition. The objective of our study was to screen commercial groundnut genotypes in Ghana for Cercospora leaf spots (early and late combined) resistance using both phenotypic and molecular (SSR markers) tools.

\section{MATERIAL AND METHODS}

\section{Plant materials}

Twenty (20) groundnut genotypes comprising 10 each of fastigiata and hypogaea subspecies (Table 1) were used for the study. Genotypes 'ICG7878' and '55-437' served as resistant and susceptible checks respectively.

Table 1 Characteristics and sources of collection of groundnut genotypes used for the study

\begin{tabular}{|c|c|c|c|c|}
\hline Genotype & $\begin{array}{c}\text { Sub- } \\
\text { species }\end{array}$ & $\begin{array}{l}\text { Days to } \\
\text { maturity }\end{array}$ & $\begin{array}{c}\text { Seed } \\
\text { colour }\end{array}$ & Source of collection \\
\hline '1CG7878' & Hypogaea & 120 & Dark rose & ICRISAT, Niger \\
\hline '55-437' & Fastagiata & 90 & Pink seed & ICRISAT, Niger \\
\hline 'Obolo' & Fastagiata & $105-110$ & Brown & CSIR-CRI, Ghana \\
\hline 'Oboshie' & Fastagiata & $105-110$ & Brown & CSIR-CRI, Ghana \\
\hline 'Yenyawoso' & Fastagiata & 90 & Dark Red & CSIR-CRI, Ghana \\
\hline 'Bremawuo' & Fastagiata & 90 & Dark Red & CSIR-CRI, Ghana \\
\hline 'Kumawu’' & Fastagiata & 90 & Brown & CSIR-CRI, Ghana \\
\hline 'Konkoma' & Fastagiata & 90 & Brown & CSIR-CRI, Ghana \\
\hline 'Jenkaar' & Hypogaea & $110-120$ & Brown & CSIR-CRI, Ghana \\
\hline 'Adepa' & Hypogaea & $110-120$ & Brown & CSIR-CRI, Ghana \\
\hline 'Nkosour' & Hypogaea & $110-120$ & Brown & CSIR-CRI, Ghana \\
\hline 'Azivivi’' & Hypogaea & 110 & Brown & CSIR-CRI, Ghana \\
\hline 'Shitaochi' & Fastagiata & $86-90$ & Brown & CSIR-CRI, Ghana \\
\hline 'Nkatekokoo' & Fastagiata & $86-90$ & Dark Red & CSIR-CRI, Ghana \\
\hline 'Behenase' & Fastagiata & 90 & Dark Red & CSIR-CRI, Ghana \\
\hline 'Manipinta' & Hypogaea & $110-120$ & Variegated & CSIR-CRI, Ghana \\
\hline 'Otuhia' & Hypogaea & $110-115$ & Brown & CSIR-CRI, Ghana \\
\hline 'GK7' & Hypogaea & $110-120$ & Brown & CSIR-CRI, Ghana \\
\hline 'Nkatiesari' & Hypogaea & 110 & Light tan & CSIR-CRI, Ghana \\
\hline 'Sumnut22' & Hypogaea & $110-120$ & Brown & CSIR-CRI, Ghana \\
\hline
\end{tabular}

Legend: ICRISAT-International Crops Research Institute for the Semi-Arid Tropics, CSIRCRI-Council for Scientific and Industrial Research-Crop Research Institute 


\section{Phenotypic screening}

\section{Experimental site and design}

Phenotypic screening was conducted in a plant house at Crops Research Institute (CRI), Fumesua- Kumasi, Ghana. It is located in semi-deciduous forest zone and has rainfall of $1500-2000 \mathrm{~mm}$ per annum. The experimental design used was completely randomised design with five pots per genotype. A sandy-loam soil rich in organic manure was steam-sterilised using barrel-steam method. Plastic containers of $60 \mathrm{~cm}$ in diameter were filled with the soil and used. Two seeds were sown per container and later thinned to one. Plants were inoculated using hand atomizer by spraying spore suspensions of early and late leaf spots pathogens at 30 and 40 days after sowing (DAS) respectively, with a spore concentration of approximately $5.4 \times 10^{5}$ conidia per $\mathrm{ml}$. The pathogens were isolated from fresh infected groundnut leaflets on plants growing on the field at CRI, Fumesua-Kumasi, Ghana. The inoculation was done in the evening, between the hours of 17.30 and 18.00. Inoculated plants were irrigated the following day in the evening and thereafter when necessary to ensure disease build up.

\section{SSR molecular screening}

Molecular screening of the 20 groundnut varieties was carried out in the Molecular Biology Laboratory of CRI, Fumesua- Kumasi, Ghana. Genomic DNA of the 20 genotypes was extracted using the Qiagen protocol. Hundred milligrams $(100 \mathrm{mg})$ of newly expanded leaves was weighed into eppendorf tubes and ground to fine powder with liquid nitrogen. Four hundred microliters $(400 \mu 1)$ Buffer AP
1 and $4 \mu \mathrm{l}$ RNase A (100mg/ml) were added to each powered leaf sample and vortexed vigorously to mix. The mixture was incubated at $65^{\circ} \mathrm{C}$ for $10 \mathrm{~min}$ and mixed by inversion. One hundred and thirty microliters $(130 \mu 1)$ Buffer AP 2 was added to the lysate, mixed and incubated on ice for $5 \mathrm{~min}$. It was then centrifuged at $14000 \mathrm{rpm}$ for $5 \mathrm{~min}$. The lysate was pipetted into a QIA shredder mini-spin coloumn and centrifuged at $14000 \mathrm{rpm}$ for $2 \mathrm{~min}$. The flow-through fraction was transferred into a new eppendorf tube without disturbing the cell debris pellet Buffer AP3/E (1.5 volumes) was added to lysate and mixed. Six hundred and fifty microliters $(650 \mu 1)$ of the mixture including any precipitate that was formed was pipetted into a DNeasy mini-spin coloumn and centrifuged at $8000 \mathrm{rpm}$ for $1 \mathrm{~min}$. Flow-through was discarded and collection tube reused. Six hundred and fifty microliters $(650 \mu \mathrm{l})$ of the remaining mixture was again pipetted into the DNeasy mini-spin coloumn and centrifuged at $8000 \mathrm{rpm}$ for $1 \mathrm{~min}$. Flow-through and collection tube were discarded. The DNeasy mini-spin space was placed into a new 2-ml collection tube and $500 \mu \mathrm{l}$ buffer AW added. It was centrifuged at $8000 \mathrm{rpm}$ for $1 \mathrm{~min}$, flow-through discarded and the collection tube reused. Buffer AW $(500 \mu \mathrm{l})$ was added to the DNeasy mini-spin coloumn and centrifuged at $14000 \mathrm{rpm}$ for $2 \mathrm{~min}$. Spin was emptied for $2 \mathrm{~min}$. DNeasy mini-spin coloum was transferred to a 2-ml tube; $50 \mu 1$ of Buffer $\mathrm{AE}$ was pipetted directly unto the DNeasy membrane, incubated at room temperature for $10 \mathrm{~min}$ and centrifuged at $8000 \mathrm{rpm}$ for $1 \mathrm{~min}$ to elute. This step was repeated. The quality of the DNA was checked using $0.8 \%$ agarose gel electrophoresis and bands compared to a DNA standard. The DNA of each genotype was primed using eight selected SSR markers (Table 2) reported to be linked to leaf spots resistance in groundnuts in previous studies (Mace $\boldsymbol{e t}$ al., 2006; Shoba $\boldsymbol{e t}$ al., 2012). The markers were purchased from Metabion International AG, Germany.

Table 2 The sequences of forward $(\mathrm{F})$ and reverse $(\mathrm{R})$ primers and annealing temperatures of SSR markers used

\begin{tabular}{llc}
\hline SSR primers & Sequences (5'-3') & Anealing Temperature $\left({ }^{\circ} \mathbf{C}\right)$ \\
\hline PM384-F & GGCGTGCCAATAGAGGTTTA & 52.0 \\
PM384-R & TGAAAACCAACAAGTTTAGTCTCTCT & 52.0 \\
pPGPseq5D5-F & AAAAGAAAGACCTTCCCCGA & \\
pPGPseq5D5-R & GCAGGTAATCTGCCGTGATT & 55.0 \\
PM375-F & CGGCAACAGTTTTGATGGTT & \\
PM375-R & GAAAAATATGCCGCCGTTG & 60.0 \\
PMc588-F & CCATTTTGGACCCCTCAAAT & \\
PMc588-R & TGAGCAATAGTGACCTTGCATT & 50.4 \\
pPGPseq2B10-F & AATGCATGAGCTTCCATCAA & \\
pPGPseq2B10-R & AACCCCATCTTAAAATCTTACCAA & 50.4 \\
pPGPseq2F5-F & TGACCAAAGTGATGAAGGGA & \\
pPGPseq2F5-R & AAGTTGTTTGTACATCTGTCATCG & 50.4 \\
pPGSseq13A7-F & AATCCGACGCAATGATAAAAA & 5 \\
pPGSseq13A7-R & TCCCCTTATTGTTCCAGCAG & 52.0 \\
pPGSseq17F6-F & CGTCGGATTTATCTGCCAGT & \\
pPGSseq17F6-R & AGTAGGGGCAAGGGTTGATG & \\
\hline
\end{tabular}

The polymerase chain reaction mixtures $(10 \mu 1)$ contained $1 \mu 1$ template DNA (5ng), $1 \mu \mathrm{l}$ of $10 \mathrm{xTaq}$ buffer, $0.9 \mu \mathrm{l} \mathrm{MgCl}_{2}(25 \mathrm{mM}), 0.2 \mu \mathrm{l}$ of dNTPs $(20 \mathrm{mM})$, $0.5 \mu \mathrm{l}$ of primers $10 \mu \mathrm{M}$ (Forward and Reverse), $0.12 \mu 1$ of Taq polymerase (Super Therm) and $5.78 \mu 1$ of sterile double distilled water. Amplification was performed in $0.2 \mathrm{ml}$ thin-walled PCR plates (96wells/plate) in a thermal cycler (Applied Biosystems). The samples were initially incubated at $94.0^{\circ} \mathrm{C}$ for $2 \mathrm{~min}$ followed by 35 cycles of $94.0^{\circ} \mathrm{C}$ for $45 \mathrm{~s}, 50.4^{\circ} \mathrm{C}-60.0^{\circ} \mathrm{C}$ for $30 \mathrm{~s}$ (optimized individually for each SSR primer as in Table 2) and $72.0^{\circ} \mathrm{C}$ for $1 \mathrm{~min} 30 \mathrm{~s}$. Final extension was $72.0{ }^{\circ} \mathrm{C}$ for $10 \mathrm{~min}$ and incubated at $4^{\circ} \mathrm{C}$ at infinity. Amplified products were analyzed using $6 \%$ non-denaturing polyacrylamide gel. Hundred base pair (100bp) ladder was usedas standardladder. Electrophoresis was carried out at a constant power of $100 \mathrm{~V}$ for $1 \mathrm{hr} 40 \mathrm{mins}$ and gel was silver-stained.

\section{Data collected}

Percentage of leaves infected by leaf spots per plant at 60 DAS and 90 DAS and the percentage of leaves defoliated at 75 DAS and 90 DAS were recorded for each plant using the expressions:

$$
\begin{aligned}
& \text { Percentage of leaves infected per plant } \\
& =\frac{\text { Number of leaves infected per plant }}{\text { Total number of leaves per plant }} \times 100 \\
& \text { Percentage defoliation }=\frac{\text { Number of leaves defoliated per plant }}{\text { Total number of leaves per plant }} \times 100
\end{aligned}
$$

Leaf spots disease severitywas assessed on each plant using a rating scale of 1-9 (Subrahmanyam et al.,1995). Groundnut varieties that had disease scores between 4 and 6 were considered as moderately resistant while those that had score of 7 were considered as susceptible. The diameters of 5 randomly selected lesions on the leaves of the main stem of each plant were recorded at 60 DAS for ELS and at 80 DAS for LLS.
DNA banding profiles were scored for power marker analysis as presence $(+)$ or absence (-) for the expected leaf spots resistant and susceptible alleles (base pairs) for each groundnut genotype as reported by Mace $\boldsymbol{e t}$ al. (2006) and Shoba et al. (2012). Individual bands were also scored as presence (1) or absence (0) for genetic cluster analysis.

\section{Statistical analysis}

Percentage data were transformed using arcsine transformation in Microsoft Excel prior to analysis of variance. Genstat statistical software (12.0 edition) was used for analysis of variance and to find correlations between means. The means were separated using Tukey's HSD at 5\%. The Genstat software was also used for cluster analysis of phenotypic data to generate a dendrogram using Euclidean Similarity Matrix and Group Average Method. Summary statistics about the SSR markers were calculated using power marker software (3.25). Also, NTSYS software (2.2) was used for hierarchical cluster analysis of SSR marker data to generate a dendrogram using Unweighted Pair Group Method with Arithmetic Mean (UPGMA) algorithm and Simple Matching Similarity Coefficient Sequential and Hierarchial Nested (SAHN) option was employed (Rohlf, 2000).

\section{RESULTS}

Differences in percentage of leaves infected with the disease and average percentage of leaves defoliated per plant were highly significant $(\mathrm{p}<0.01)$ among the 20 genotypes (Table 3). Genotype '55-437' (a fastigiata from ICRISAT, Niger) had the highest percentage of leaves infected per plant whiles 'Nkosour' (hypogaea) had the lowest at 60 DAS. Again, at 90 DAS, 55-437 had the highest leaf incidence per plant whiles 'Manipinta' (hypogaea) had the lowest(Table 3) Also, 'Manipinta' had the lowest percentage defoliation and 'Konkoma' (a fastigiata) had the highest at 75 DAS. At 90 DAS, 'Nkosour' had the lowest percentage defoliation and 'Konkoma' again had the highest (Table 3). 
Table 3 Mean percentage of leaves infected and defoliation per plant (Transformed)

\begin{tabular}{lcccc} 
& \multicolumn{2}{c}{ Leaves infected/plant } & \multicolumn{2}{c}{ Defoliation/Plant } \\
\cline { 2 - 5 } Genotypes & $60 \mathrm{DAS}$ & $90 \mathrm{DAS}$ & $75 \mathrm{DAS}$ & $90 \mathrm{DAS}$ \\
\hline '1CG7878' & 24.42 & 51.98 & 27.89 & 31.51 \\
'55-437' & 39.07 & 72.18 & 32.38 & 39.73 \\
'Obolo' & 28.25 & 61.92 & 29.59 & 35.40 \\
'Oboshie' & 32.58 & 56.78 & 30.29 & 32.87 \\
'Yenyawoso' & 35.93 & 62.50 & 31.87 & 39.93 \\
'Bremawuo' & 32.14 & 67.08 & 30.97 & 36.91 \\
'Kumawu' & 37.58 & 63.16 & 31.64 & 42.71 \\
'Konkoma' & 35.24 & 69.64 & 36.61 & 49.22 \\
'Jenkaar' & 30.00 & 53.37 & 28.32 & 31.35 \\
'Adepa' & 28.23 & 54.37 & 28.56 & 39.77 \\
'Nkosour' & 19.47 & 54.82 & 25.65 & 28.05 \\
'Azivivi' & 33.96 & 58.85 & 26.72 & 29.66 \\
'Shitaochi' & 34.95 & 59.89 & 30.39 & 41.86 \\
'Nkatekokoo' & 36.61 & 62.05 & 29.96 & 31.71 \\
'Behenase' & 32.15 & 59.06 & 27.23 & 35.05 \\
'Manipinta' & 24.82 & 51.52 & 23.65 & 28.79 \\
'Otuhia' & 24.55 & 55.47 & 24.76 & 28.21 \\
'GK7' & 20.30 & 53.50 & 26.94 & 31.62 \\
'Nkatiesari' & 22.57 & 54.27 & 24.16 & 28.87 \\
'Sumnut22' & 26.86 & 52.95 & 25.30 & 37.06 \\
\hline Mean & 29.98 & 58.77 & 28.64 & 35.01 \\
CV (\%) & 11.80 & 8.70 & 6.50 & 6.30 \\
Tukey's HSD & $8.359 * *$ & $12.259 * *$ & $4.289 * *$ & $5.199 * *$ \\
(5\%) & & & \\
\hline
\end{tabular}

Legend:**-significant at $\mathrm{p}<0.01$, DAS-days after sowing, HSD-highest significant difference value

Figure $1 \mathrm{a}$ and $\mathrm{b}$ show early and late leaf spots infections on the leaflets of innoculated groundnut. Average leaf spots disease severity scores (early and late combined) and lesion diameters differed significantly $(\mathrm{p}<0.01)$ among the genotypes (Table 4). At 60 DAS, 'ICG7878', 'Jenkaar', 'Manipinta', 'GK7' and 'Nkatiesari' (hypogaea genotypes) had the lowest severity scores whiles '55437', 'Konkoma' and 'Shitaochi' (fastigiata) had the highest. 'ICG7878' had the lowest score at 90 DAS whiles '55-437', 'Yenyawoso', 'Bremawuo', 'Kumawu', 'Konkoma' and 'Shitaochi' had the highest. Genotype '55-437' had the largest lesion diameter for both early and late leaf spots. 'Jenkaar' (a hypogaea subspecies) had the smallest early leaf spot lesion diameter whilst 'Manipinta' (a hypogaea) had the smallest late leaf spot lesion diameter. The lesion diamete ranged from 2.3 to $4.3 \mathrm{~mm}$ for early leaf spot and 1.4 to $3.1 \mathrm{~mm}$ for late leaf spo (Table 4). The disease components assessed were highly and positively correlated among each other (Table 5).

Table 4 Mean leaf spots disease severity score (Scale 1-9) and lesion diameter (mm) among the groundnut genotypes

\begin{tabular}{|c|c|c|c|c|}
\hline Genotype & $\begin{array}{l}\text { Severity } \\
\text { score at } \\
60 \text { DAS }\end{array}$ & $\begin{array}{c}\text { Severity } \\
\text { score } \\
\text { 90 DAS }\end{array}$ & $\begin{array}{c}\text { ELS } \\
\text { Lesion } \\
\text { diameter } \\
\text { 60DAS } \\
(\mathrm{mm})\end{array}$ & $\begin{array}{c}\text { LLS } \\
\text { Lesion } \\
\text { diameter } \\
\text { 80 DAS } \\
(\mathrm{mm})\end{array}$ \\
\hline '1CG7878' & 3.00 & 4.00 & 2.73 & 2.00 \\
\hline '55-437' & 5.00 & 7.00 & 4.30 & 3.10 \\
\hline 'Obolo' & 3.20 & 6.00 & 3.10 & 2.40 \\
\hline 'Oboshie' & 4.00 & 5.00 & 2.37 & 1.97 \\
\hline 'Yenyawoso' & 4.00 & 7.00 & 3.47 & 2.63 \\
\hline 'Bremawuo' & 4.00 & 7.00 & 3.50 & 2.50 \\
\hline 'Kumawu' & 4.20 & 7.00 & 3.73 & 2.77 \\
\hline 'Konkoma' & 5.00 & 7.00 & 3.23 & 2.70 \\
\hline 'Jenkaar' & 3.00 & 5.00 & 2.23 & 1.80 \\
\hline 'Adepa' & 4.00 & 5.00 & 2.77 & 2.10 \\
\hline 'Nkosour' & 4.00 & 5.00 & 2.50 & 1.50 \\
\hline 'Azivivi' & 3.20 & 5.80 & 2.93 & 2.07 \\
\hline 'Shitaochi' & 5.00 & 7.00 & 4.07 & 2.90 \\
\hline 'Nkatekokoo' & 4.00 & 6.00 & 3.43 & 1.97 \\
\hline 'Behenase' & 4.00 & 6.00 & 3.47 & 2.37 \\
\hline 'Manipinta' & 3.00 & 5.00 & 2.37 & 1.40 \\
\hline 'Otuhia' & 3.40 & 5.00 & 2.67 & 1.63 \\
\hline 'GK7' & 3.00 & 5.00 & 2.83 & 1.53 \\
\hline 'Nkatiesari' & 3.00 & 4.20 & 2.53 & 1.70 \\
\hline 'Sumnut22' & 3.80 & 5.00 & 3.10 & 1.50 \\
\hline Mean & & & & \\
\hline $\mathrm{CV}(\%)$ & 3.19 & $\begin{array}{l}5.70 \\
2.50\end{array}$ & 3.07 & 2.13 \\
\hline Tukey's HSD & $\begin{array}{c}6.20 \\
0.59 * *\end{array}$ & $\begin{array}{c}2.50 \\
0.79 * *\end{array}$ & $\begin{array}{c}9.00 \\
0.599 * *\end{array}$ & $\begin{array}{c}10.30 \\
0499 * *\end{array}$ \\
\hline$(5 \%)$ & $0.59 \cdots$ & $0.79 \times-1$ & & \\
\hline
\end{tabular}

Legend: $* *$-significant at $\mathrm{p}<0.01$, DAS-days after sowing, ELS-early leaf spots, LLS-late leaf spots, HSD-highest significant difference value
Table 5 Correlation among disease components (Phenotypic)

\begin{tabular}{ccccccccc}
\hline & $\mathbf{1}$ & $\mathbf{2}$ & $\mathbf{3}$ & $\mathbf{4}$ & $\mathbf{5}$ & $\mathbf{6}$ & $\mathbf{7}$ & $\mathbf{8}$ \\
\hline $\mathbf{1}$ & - & & & & & & \\
$\mathbf{2}$ & $0.76^{* *}$ & - & & & & & \\
$\mathbf{3}$ & $0.66^{*}$ & $0.72^{* *}$ & - & & & & \\
$\mathbf{4}$ & $0.81^{* *}$ & $0.88^{* *}$ & $0.74 * *$ & - & & & \\
$\mathbf{5}$ & $0.75^{* *}$ & $0.82^{* *}$ & $0.72^{* *}$ & $0.76^{* *}$ & - & & \\
$\mathbf{6}$ & $0.64 *$ & $0.67 *$ & $0.77 * *$ & $0.73^{* *}$ & $0.83^{* *}$ & - & & \\
$\mathbf{7}$ & $0.72^{* *}$ & $0.77^{* *}$ & $0.73^{* *}$ & $0.83^{* *}$ & 0.59 & $0.66^{*}$ & - & \\
$\mathbf{8}$ & $0.82^{* *}$ & $0.84^{* *}$ & $0.73^{* *}$ & $0.85^{* *}$ & $0.82^{* *}$ & $0.78^{* *}$ & $0.84 * *$ & - \\
\hline
\end{tabular}

Legend: ***-correlation coefficient significantly different from zero at $p<0.05$ and $p<0.01$, respectively, 1-percentage of leaves infected/plant at $60 \mathrm{DAS}$, 2-percentage of leaves infected/plant at 90 DAS, 3-severity score at 60 DAS,4-severity score at 90 DAS, 5 percentage defoliation at 75 DAS, 6-percentage defoliation at 90 DAS,7-ELS lesion diameter at 60DAS,8-LLS lesion diameter at 80 DAS.
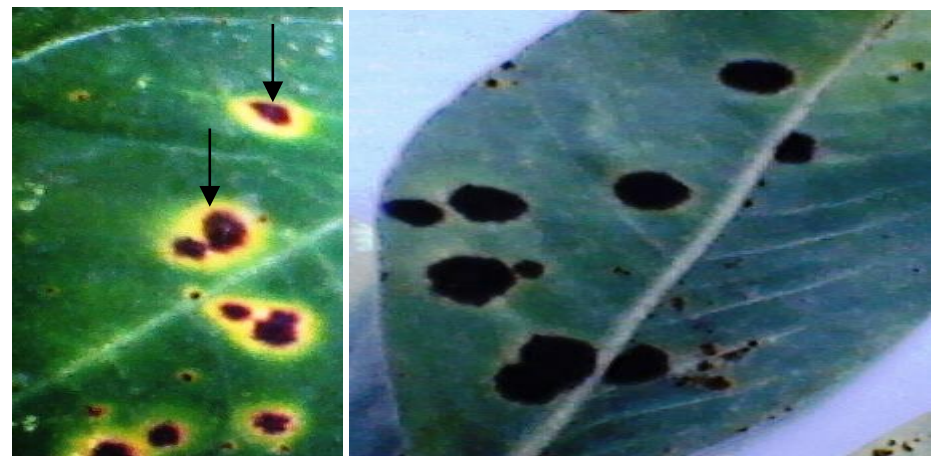

Figure 1a ELS on upper surface of innoculated groundnut leaflet

Figure 1b LLS on the lower surface of inoculated groudnut leaflet

Legend: ELS-early leaf spots, LLS-late leaf spots

A dendrogram based on the disease components data is shown in Figure 2. At the phenotypic level, the genotypes were grouped into two clusters at 0.85 similarity co-efficient. Cluster 'A' was made up of 12 genotypes; all were moderately resistant to leaf spots disease. Cluster ' $\mathrm{B}$ ' was made up of eight (8) genotypes; all were susceptible except 'Nkatekokoo' and 'Behanase'.

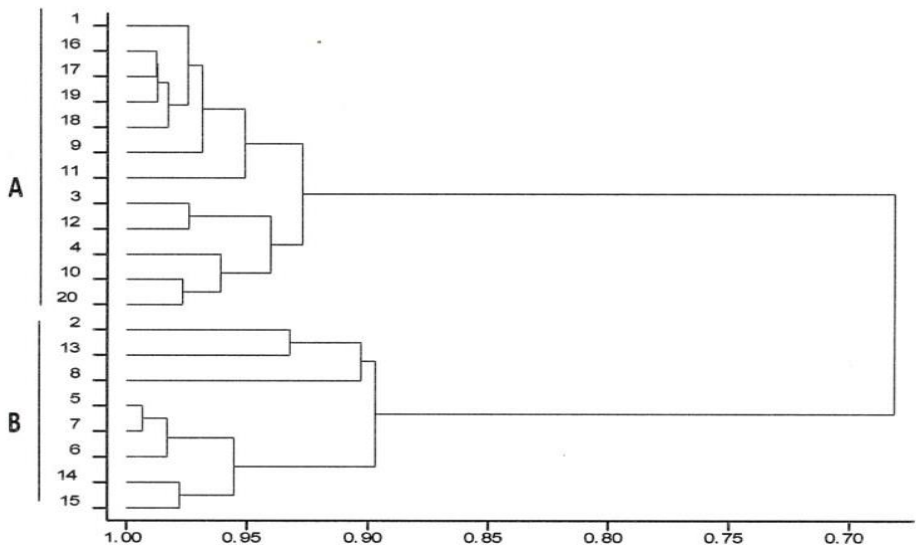

Figure 2 Dendrogram of 20 groundnut genotypes based on phenotypic resistance to leaf spots constructed using Euclidean Similarity Matrix and Group Average method

Legend:1-'ICG7878', 2-'55-437', 3-'Obolo', 4-'Oboshie', 5-'Yenyawoso', 6-'Bremawuo', 7-'Kumawu', 8-'Konkoma', 9-'Jenkaar', 10-'Adepa', 11-'Nkosour', 12-'Azivivi', 13 'Shitaochi',14-'Nkatekokoo', 15-'Behenase', 16-'Manipinta', 17-'Otuhia', 18-'GK7', $19-$ 'Nkatiesari', 20-'Sumnut22'.

Summary statistics of the eight SSR markers used to screen the 20 genotypes of groundnuts for leaf spot resistance are presented in Table 6. Primers PM384 and pPGPseq5D5 had the highest gene diversity and PMC588 had the lowest. The highest percentage heterozygosity was recorded for primers pPGPseq2F5, pPGPseq5D5 and PMC588 while PM 375 had the lowest. Polymorphic information content (PIC) values of the primers ranged from 0.55 to 0.85 with pPGPseq5D5 and PM384 having the highest values. 
Table 6 Allelic frequency, number of alleles, gene diversity, heterozygosity and PIC values

\begin{tabular}{lccccc}
\hline SSR marker & Allele frequency & Allele no. & Gene diversity & Heterozygosity & PIC \\
\hline pPGPseq2F5 & 0.26 & 11.00 & 0.84 & 1.00 & 0.83 \\
pPGPseq2B10 & 0.34 & 13.00 & 0.83 & 0.94 & 0.82 \\
pPGPseq13A7 & 0.32 & 10.00 & 0.79 & 0.95 & 0.76 \\
pPGPseq17F6 & 0.27 & 11.00 & 0.84 & 0.92 & 0.83 \\
PM384 & 0.20 & 10.00 & 0.87 & 0.87 & 0.85 \\
PM375 & 0.29 & 10.00 & 0.81 & 0.57 & 0.79 \\
pPGPseq5D5 & 0.21 & 9.00 & 0.87 & 1.00 & 0.85 \\
PMC588 & 0.50 & 3.00 & 0.63 & 1.00 & 0.55 \\
\hline Mean & 0.30 & 9.62 & 0.81 & 0.91 & 0.78 \\
\hline
\end{tabular}

Legend: PIC-polymorphic information content

A dendrogram based on the eight SSR markers showing genetic relationship among the 20 genotypes used is shown in Figure 3. The genotypes were clustered into five groups at $70 \%$ similarity index (Figure 3). Cluster 'A' comprises 14 genotypes. This group contains eight hypogaea and six fastigiata genotypes. All the genotypes in this cluster are commercially cultivated in Ghana, except 'ICG7878'. The genotypes in this cluster were moderately resistant to leaf spots under phenotypic screening, except 'Kumawu', 'Konkoma', 'Yenyawoso' and 'Bremawuo' which were susceptible and were also grouped separately within cluster 'A'. Two leaf spot-resistant hypogaea genotypes ('GK7' and 'Nkatiesari') were also grouped separately at $89 \%$ similarity index within cluster 'A'. Clusters
'B' and ' $\mathrm{C}$ ' are made up of 'Shitaochi' and '55-437', respectively. These genotypes are fastigiata subspecies and susceptible to leaf spot disease under phenotypic screening. Cluster ' $D$ ' comprises three moderately resistant varieties ('Nkatekoo', 'Behenase' and 'Sumnut22') grown in Ghana. 'Nkatekokoo' and 'Behenase' which have red seed coat are grouped separately under this cluster at $74 \%$ similarity index. Finally, cluster ' $E$ ' is made up of 'Otuhia', a leaf spotresistant hypogaea variety released together with 'Obolo', 'Oboshie' and 'Yenyawoso' in 2012 by CRI, Ghana (Ghana Money News and Information, 2012)

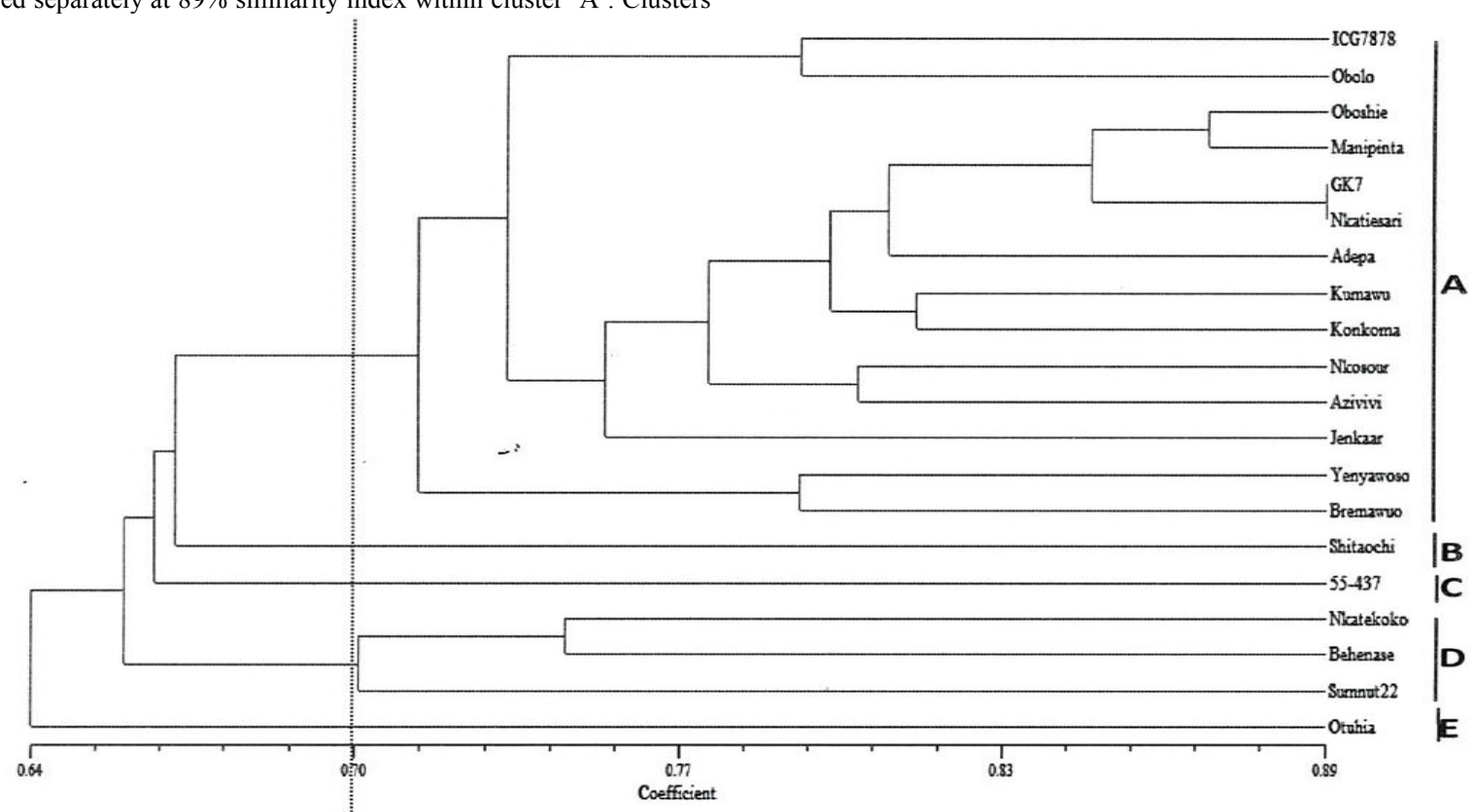

Figure 3 Dendrogram of the 20 groundnut varieties based on the SSR markers constructed using UPGMA with Simple Matching similarity coefficient

Figure 4 shows the banding pattern of primer pPGPseq2F5. Primer pPGPseq2F5 identified 13 genotypes ('ICG7878', 'Obolo', 'Oboshie', 'Kumawu', 'Jenkaar', 'Adepa', 'Nkosour', 'Behenase', 'Manipinta', 'Otuhia', 'GK7', 'Nkatiesari' and 'Sumnut22') at the expected resistant allele (280bp).Primer pPGPseq2B10 identified 10 genotypes ('ICG7878', 'Yenyawoso', 'Jenkaar', 'Azivivi', 'Nkatekokoo', 'Behenase', 'Otuhia', 'GK7', 'Nkatiesari' and 'Sumnut22') at the expected resistant allele $280 \mathrm{bp}$ and additional three genotypes ('Nkosour', 'Azivivi' and 'Manipinta') at 290bp. Primer pPGPSseq13A7 identified three genotypes ('55-347', 'Yenyawoso' and 'Bremawuo') at the expected susceptible 305bp. Also, pPGPSseq17F6 alone was able to identify seven genotypes ('ICG7878', '55-437', 'Oboshie', 'Adepa', 'Nkatekokoo', 'Behenase' and 'Manipinta') at $120 \mathrm{bp}$, four genotypes ('Jenkaar', 'Nkosour', 'Azivivi' and 'Nkatiesari') at 140bp and three genotypes ('Obolo', 'Nkatekokoo' and 'Sumnut22') at 150bp as resistant. PM 375 identified five genotypes ('Oboshie', 'Bremawuo', 'Behenase', 'Manipinta' and 'Nkatiesari') at 162bp and pPGPseq5D5 identified seven genotypes ('Kumawu', 'Konkoma', 'Jenkaar', 'Adepa', 'Azivivi', 'Shitaochi' and 'Behenase') at 220bp as resistant. Primer PM384 also identified 12 genotypes ('Obolo', 'Yenyawoso', 'Bremawuo', 'Jenkaar', 'Adepa', 'Azivivi', 'Nkatekokoo', 'Manipinta', 'Otuhia', 'GK7', 'Nkatiesari' and 'Sumnut22') as resistant at the expected 100bp allele. PMc588 identified 11 genotypes ('ICG7878', 'Oboshie', 'Jenkaar', 'Adepa', 'Nkosour', 'Azivivi', 'Manipinta', 'Otuhia', 'GK7', 'Nkatiesari' and 'Sumnut22') as resistant at $180 \mathrm{bp}$ and $220 \mathrm{bp}$.

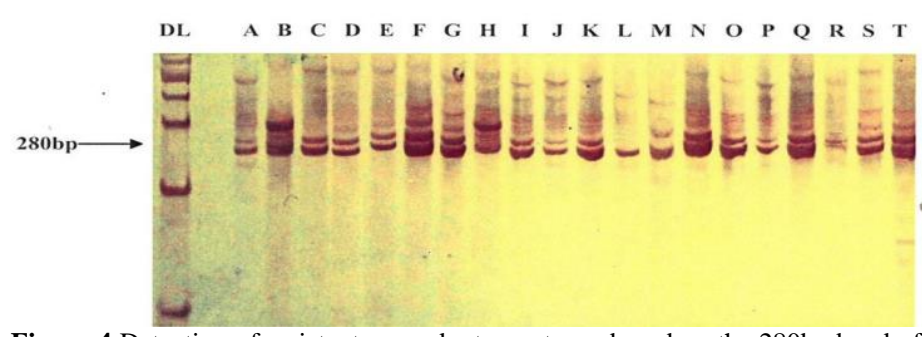

Figure 4 Detection of resistant groundnut genotypes based on the 280bp band of Primer pPGseq2F5 PCR amplification products

Legend:DL-100bp DNA ladder, A-'ICG7878', B-'55-437', C-'Obolo', D-'Oboshie', E'Yenyawoso', F-'Bremawuo', G-'Kumawu', H-'Konkoma',I-'Jenkaar', J-'Adepa', K'Nkosour', L-'Azivivi', M-'Shitaochi', N-'Nkatekokoo', O-'Behenase', P-'Manipinta', Q'Otuhia', R-'GK7',S-'Nkatiesari', T-'Sumnut22'.

\section{DISCUSSIONS}

Disease development on individual plants from 60 to 90 DAS indicated that leaf spots disease affected a greater proportion of leaves in fastigiata subspecies compared to the hypogaea group. The susceptible cultivars had a higher percentage of leaves infected by the disease since severity score was highly and 
positively associated with leaf spots incidence per plant. Leaf spots infection caused defoliation as seen by the high percentage of leaf defoliation at 75 DAS and 90 DAS, which was highly and positively associated with other disease components. Most of the moderately resistant cultivars were found among genotypes with low levels of defoliation. Thus, leaf spots resistant genotypes maintained more leaves on the plant than their susceptible counterparts Generally, genotypes from subspecies hypogaea had lower disease severity scores. Phenotypically, no variety was completely resistant to Cecospora leaf spots disease. However, 14 genotypes ('ICG7878', 'Obolo', 'Oboshie', 'Jenkar', 'Adepa', 'Nkosour', 'Azivivi', 'Nkatekokoo', 'Behenase', 'Manipinta', 'Otuhia', 'GK7', 'Nkatiesari' and 'Sumnut22') were moderately resistant by 90 DAS. This finding confirms similar results reported by Gaikpa et al. (2015) about these groundnut genotypes under natural field infection. On the other hand, leaf spots scores recorded for genotype 'ICG7878',from ICRISAT, Niger,was in contrast to a score of 2 found in Burkina Faso (Ntare and Waliyar, 1994). The inconsisten performance of this genotype is not unusual since groundnut reaction to Cercospora leaf spots disease has been found as a polygenic trait (Dwivedi et al. 2002; Janila et al., 2013b), hence highly influenced by environment. The quantity of innoculum, interaction among hosts, pathogen race and environmen or heterogeneity of germplasm influence leaf spots disease severity in groundnuts (McDonald et al., 1985). Lesion size was found to be larger in genotypes with higher disease severity scores. In a related work, Dwivedi et al. (2002) also found a significant and high correlation between lesion diameter and disease score. The lesion diameter for early leaf spots was larger than those of late leaf spots. The larger size of early leaf spot lesion could be as result of the fact that the causative pathogen, $C$. arachidicola,might grow faster than that of late leaf spot, $C$ personatum. Genotypes found to be moderately resistant in this study had a maximum ELS lesion size of $3.5 \mathrm{~mm}$ and LLS lesion size of $2.4 \mathrm{~mm}$ while more susceptible ones had a maximum ELS lesion size of $4.3 \mathrm{~mm}$ and LLS lesion size of $3.1 \mathrm{~mm}$. This implies that leaf spots-resistant cultivars might have a mechanism (molecular or chemical) to inhibit the growth of the fungi and thus prevent formation of larger lesions on the surface of groundnut leaflets. Lesion diameter of early leaf spots was significantly and highly correlated with that of late leaf spots. This shows that varieties that were resistant to early leaf spots were also resistant to late leaf spots. This indicates a possible genetic linkage or host-plant physiology that confers resistance to both early and late leaf spot diseases in a groundnut population (Janila et al., 2013b)

Polymorphic information content (PIC) value is an indication of how useful a genetic marker is for linkage analysis (Elston, 2005; Shete et al., 2000). The high PIC mean value (78\%) observed in this study indicates that the markers were highly informative (Hildebrand $\boldsymbol{e} t \boldsymbol{a l}$., 1992) for the genotypes.The finding confirmed that the genotypes were of different genetic backgrounds. In earlier studies, high PIC values were reported for primers PM 384 and PM 375 (Tang et al., 2007). Grouping of groundnut varieties with similar reaction to leaf spots disease within a cluster in this study for both phenotypic and molecular cluster analysis could indicate that a common gene confer leaf spots resistance in groundnut. Similarly, Bera et al. (2014) have reported clustering of groundnut genotypes with the same reaction to groundnut bud necrosis disease into one group.

Most of the groundnut genotypes identified by the molecular markers as resistant to leaf spots at the expected alleles reported by Mace $\boldsymbol{e t}$ al. (2006) and Shoba $\boldsymbol{e}$ al. (2012) were also found to be resistant under phenotypic screening both in the present study and the previous field study of Gaikpa et al. (2015). For instance, 12 genotypes $(92.31 \%)$ identified by primer pPGseq2F5 280 ; all $(100 \%)$ the genotypes identified by PMc588 $180 / 220 ; 12$ genotypes $(92.31 \%)$ identified by pPGseq2B $10_{280 / 290} ; 10$ genotypes $(83.33 \%)$ identified by PM $384_{100} ; 13$ genotypes $(92.86 \%)$ by pPGSseq $17 \mathrm{F6}_{120 / 140 / 150}$ and four genotypes $(80.00 \%)$ identified by PM375 162 as resistant were also found to be moderately resistant to the disease under phenotypic screening. All the three susceptible genotypes indentified by pPGPseq $13 \mathrm{~A} 7_{305}$ agreed with phenotypic screening. This confirms that these genotypes were genetically resistant or otherwise susceptible to leaf spots disease. Therefore, the genetic composition of the groundnut genotypes might have accounted for their level of resistance to the disease at the phenotypic level. Moreover, in the absence of DNA molecular markers to identify resistance, morphological descriptors could also be used, in the interim, to select resistant genotypes.

\section{CONCLUSION}

Resistant genotypes were found in the groundnuts studied both at molecular and phenotypic levels. The resistant genotypes confirmed by most of the markers were 'ICG7878', 'Obolo', 'Oboshie', 'Jenkar', 'Adepa', 'Nkosour', 'Azivivi', 'Nkatekokoo', 'Behenase', 'Manipinta', 'Otuhia', 'GK7', 'Nkatiesari' and 'Sumnut22'. Genotypes '55-437', 'Yenyawoso', 'Bremawuo', 'Kumawu', 'Konkoma' and 'Shitaochi' were susceptible. The SSR markers pPGseq2F5, pPGseq2B10, pPGPseq17F6, PMc588 and PM384 were able to detect most of the resistant groundnut genotypes. Hence, both molecular and phenotypic markers could be used for selection and breeding for leaf spot resistance in Ghanaian groundnuts. Future studies should aim at crossing the susceptible genotypes with the resistant ones. Also, development of more specific molecular markers for leaf spots resistance in groundnuts in Ghana should be given attention.

Acknowledgments: We thank the Catholic Academic Exchange Service (KAAD), Germany, for providing study scholarship to the first author for this study. We also thank the staff of Molecular Biology Laboratory, CRI, FumesuaKumasi, for technical assistance.

\section{REFERENCES}

Asibuo, J.Y, Akromah, R., Adu-Dapaah, K.H. and Safo-Kantanka,O. (2008) Evaluation of nutritional quality of groundnut (Arachis hypogaea L.) from Ghana. African Journal of Food, Agriculture, Nutrition and Devevelopment, 8(2), 133-150.http://dx.doi.org/10.4314/ajfand.v8i2.19185.

Bera, S.K., Kamdar, J.H., Maurya, A. K. and Dash, P. (2014). Molecular diversity and association of simple sequence repeatmarkers with bud necrosis disease in interspecific breeding lines and cultivars of peanut (Arachis hypogaed L.). AustralianJournal of Crop Science, 8(5), 771 780.http://www.cropj.com/sandip $8 \quad 5 \quad 2014 \quad 771$ 780.pdf

Dwivedi, S.L, Pande, S., Rao, J.N. and Nigam, S.N. (2002). Components of resistance to late leaf spot and rust among interspecific derivatives and their significance in a foliar disease resistancebreeding in groundnut (Arachis $\begin{array}{lll}\text { hypogaea } & \text { L.). } & \text { Euphytica, }\end{array}$ 88.http://dx.doi.org/10.1023/A:1015707301659.

Elston, C. R. (2005). Polymorphism Information Content. Encyclopedia of Biostatistics 6. http://dx.doi.org/10.1002/0470011815.b2a05078.

Fehr, W.R. (1987). Principles of cultivar development. Theory and Technique (vol. 1). USA: Mcgraw Hill Inc.

FAOSTAT[Food and Agriculture Organization Statistical Database] (2015).http://faostat3.fao.org/download/Q/QC/E.

Gaikpa, S. D., Akromah, R., Asibuo, J.Y., Nyadanu, D. and Appiah-Kubi, Z. (2015). Evaluation of yield and yield components of groundnut genotypes under Cercospora leaf spots disease pressure. International Journal of Agronomy and Agricultural Research, 7(3), 66-75.http://www.innspub.net/wpcontent/uploads/2015/09/IJAAR-V7No3-p66-75.pdf

Ghana Money News and Information (2012, August 9). MOFA Releases 16 New Crop Varieties. http://news.moneygh.com/pages/agriculture/201208/712.php.

Hildebrand, C. E., Torney, D. C. and Wagner, R. P. (1992). Informativeness of Polymorphic DNA Markers. Los Alamos Sci., 20, 100-102.

Janila, P., Nigam, S. N., Pandey, M. K., Nagesh, P. And Varshney, R. K (2013a). Groundnut improvement: use of genetic and genomic tools. Frontiers in Plant Science, 4, 23.http://dx.doi.org/10.3389/fpls.2013.00023.

Janila, P., Ramaiah, V., Rathore, A., Upakula, A., Reddy, R. K., Waliyar, F. and Nigam, S.N. (2013b). Genetic analysis of resistance to late leaf spot in interspecific groundnuts. Euphytica, 193(1), 13 25.http://dx.doi.org/10.1007/s10681-013-0881-7.

Kishore, K. G., Pande, S. and Podile, A.R. (2005). Management of late leaf spot of groundnut (Arachis hypogaea) with chlorothalonil-tolerant isolates of Pseudomonas aeruginosa. Plant Pathology, $54 \quad$ (3), 401-408. http://dx.doi.org/10.1111/j.1365-3059.2005.01160.x.

Mace, E. S., Phong, D.T., Upadhaya, H. D., Chandra, S. and Crouch, J. H. (2006). SSR analysis of cultivated groundnut (Arachis hypogaea L.) germplasm resistant to rust and late leaf spot diseases. Euphytica, 152(3), 317-330. http://dx.doi.org/10.1007/s10681-006-9218-0.

McDonald, D., Subrahmanyam, P., Gibbons, R.W. and Smith, D.H. (1985). Early and late leaf spots of groundnut. Information Bulletin No. 21. Patancheru, India: International Crops Research Institute for the Semi-Arid Tropics. http://oar.icrisat.org/821/1/RA 00080.pdf

Ntare, B. R. and Waliyar, F. (1994). The role of genetic enhancement in sustainable groundnut production in western Africa. In: Ndunguru, B. J., Hildebrand, G. L. and Subrahmanyam, P. (eds.). Proceedings of a workshop on sustainable groundnut production in Southern and Eastern Africa, 5-7 July 1994, Mbabane. Swaziland. Patancheru502 324, Andhra Pradesh, India: International Crops Research Institute for the Semi-Arid Tropics. pp.14 19.http://oar.icrisat.org/1014/1/RA 00250.pdf.

Nutsugah , S.K., Abudulai , M., Oti-Boateng , C., Brandenburg, R.L. and Jordan D.L. (2007). Management of Leaf Spot Diseases of Peanut with Fungicides and Local Detergents in Ghana. Plant Pathology Journal, 6, 248253.http://dx.doi.org/10.3923/ppj.2007.248.253.

Rohlf, F. J. (2000). Numerical taxonomy and multivariate analysis system. New York: Applied Biostatistics Inc.

Shete, S., Tiwari, H. and Elston, R. C. (2000). On estimating the heterozygosity and polymorphism information content value. Theoretical Population Biology, 57(3), 265-71.http://dx.doi.org/10.1006/tpbi.2000.1452.

Shoba, D., Manivannan, N., Vindhiyavarman, P. and Nigam, S. N. (2012). SSR markers associated for late leaf spot disease resistance by bulked segregant analysis in groundnut (Arachis hypogaea L.). Euphytica, 188(2), 265-272. http://dx.doi.org/10.1007/s10681-012-0718-9.

Subrahmanyam, P., McDonald, D., Waliyar, F., Reddy, L. J., Nigam, S. N., Gibbons, R. W., Ramanatha Rao, V. R., Singh, A. K., Pande, S., Reddy, P. M. 
and Subba Rao, P. V. (1995). Screening methods and sources of resistance to rust and late leaf spot of groundnut. Information Bulletin 47, Patancheru, India:

International Crops Research Institute for the Semi-Arid Tropics, p. 24.http://oar.icrisat.org/3477/1/PNABX110.pdf.

Tang, R., G. Gao, L. He, Z. Han, S. Shan , R. Zhong, C. Zhou, J. Jiang, Y. Li

and W. Zhuang. (2007). Genetic diversity in cultivated groundnut based on SSR

markers. Journal of Genetics and Genomics, 34(5), 449-

459.http://dx.doi.org/10.1016/S1673-8527(07)60049-6. 